\title{
Działania pomocowe na rzecz ograniczania kryzysu migracyjnego
}

\section{Aid Measures Reducing the Scale of Migration Crisis}

\author{
Magdalena Chybowska* \\ Elżbieta Trafiałek ${ }^{* *}$
}

\begin{abstract}
Abstrakt
W obliczu wzmożonej fali uchodźców i migrantów z obszarów objętych konfliktami, głównie z Syrii, Europa nie potrafi zaproponować wspólnego rozwiązania systemowego niwelującego ten problem. Kwestia uchodźcza podzieliła Wspólnotę, wzmocniła narodowe tożsamości kulturowe bądź religijne i skłoniła wielu obywateli państw członkowskich do refleksji nad postawą solidarnościową wobec migrantów. Działania pomocowe państw członkowskich Unii Europejskiej są różne W zależności od rządzących partii politycznych. W prezentowanym artykule opisano główne działania zmierzające do rozwiązania kwestii uchodźczej w Europie.
\end{abstract}

Słowa kluczowe: uchodźcy, Europa, pomoc ekonomiczna, pomoc humanitarna

\begin{abstract}
Faced with an increased wave of refugees and migrants from conflict areas, mainly Syria, Europe is unable to propose a common systemic solution to eliminate this problem. The refugee issue has divided Europe, strengthened national cultural or religious identities and made many citizens of Member States reflect on their attitude of solidarity towards migrants. The aid measures of the various Member States of the European Union vary according to the political parties in power. This article describes the main actions aimed at addressing the refugee issue in Europe.
\end{abstract}

Keywords: refugees, Europe, economic aid, humanitarian aid

* Uniwersytet Jana Kochanowskiegow Kielcach (magdalena.chybowska@yahoo.com) (iD https://orcid.org/0000-0003-1196-4764

** Uniwersytet Jana Kochanowskiego w Kielcach (elzbieta.trafialek@ujk.edu.pl)

(iD) https://orcid.org/0000-0002-7745-6191 


\section{Wprowadzenie}

Uchodźstwo i imigracja zajmowały ważne miejsce w europejskim programie politycznym już od przełomu lat 2014/2015, kiedy to w Europie odnotowano rekordową liczbę osób ubiegających się o azyl oraz niespotykany wcześniej napływ migrantów przybywających na Stary Kontynent, głównie nielegalnymi trasami. Pandemia spowodowała wyciszenie, ale nie rozwiązanie problemu. Pozornie wydawał się on coraz bardziej odległy, bo mniej widoczny. Uchodźców z Afryki i Syrii lokowano w przeludnionych obozach, głównie na terenie Grecji i Turcji. Kryzys ze zdwojoną siłą powrócił w 2021 roku, zarówno z powodu zmian klimatycznych w Afryce, wycofania wojsk amerykańskich z Afganistanu i przejęcia władzy przez talibów, jak i w wyniku polityki szantażu, prowokacji oraz terroru prowadzonej wobec Unii Europejskiej (UE) przez białoruskiego dyktatora Alaksandra Łukaszenkę. Zorganizowana przez niego wojna hybrydowa na wschodniej granicy UE zrodziła wiele nowych wyzwań humanitarnych i przed państwami graniczącymi z Białorusią (Litwą, Łotwą i Polską), i przed całą Wspólnotą. Wyzwań nowych i trudnych, bo wymagających szukania konsensu między poszanowaniem najważniejszych, gwarantowanych traktatami i konwencjami międzynarodowymi praw człowieka do życia i godności, a bezwzględnym wykorzystywaniem uchodźców jako pionków, narzędzi w bezwzględnej grze geopolitycznej (Kluth, 2021).

Obecnie idea pomocy rozwojowej jest krytykowana w zachodnich demokracjach, państwa rozwinięte bowiem stoją na stanowisku, że drogą do rozwiązania problemu migracji jest przede wszystkim dążenie do sprawiedliwości gospodarczej w kraju i za granica, uruchamianie nowej agendy wolności oraz tworzenie nowych ram pomocy - pomocy rozumianej jako działania nie tyle charytatywne, ile innowacyjne, nowatorskie - adekwatne do wyzwań współczesności. Według dostępnych statystyk międzynarodowych, w ostatniej dekadzie na całym świecie obniżył się poziom skrajnego ubóstwa, wzrósł dostęp do podstawowej opieki zdrowotnej i edukacji, a liczba ofiar śmiertelnych z powodu przemocy osiągnęła najniższy poziom w historii. To pozytywne sygnały, ale towarzyszą im też inne - budzące niepokój, w tym: rosnące nierówności ekonomiczne w poszczególnych krajach i stały wzrost liczby przymusowo wysiedlanych. Problemy potęgują zmiany klimatyczne, w słabo rozwiniętych regionach świata skutkując epidemiami suszy, powodziami, głodem, chorobami, wyniszczeniami całych społeczności, a ostatecznie i masowymi migracjami w poszukiwaniu ratunku, lepszych terenów do życia.

Przyjęcie odpowiedzialności społecznej za los takich ludzi jest jedną z podstawowych zasad funkcjonowania organizacji pozarządowych, politycznych, demokratycznych państw europejskich. Są one zaangażowane w zapewnianie uchodźcom pomocy w sytuacjach kryzysowych, pomagając też w uzyskaniu jak najlepszej integracji ze społeczeństwem. 
Do niedawna największy ciężar przyjmowania uchodźców np. z Syrii spoczywał na sąsiadach tego kraju, głównie na Turcji, Libanie i Jordanii. W 2015 roku liczba uchodźców wzrosła, a ich miejsce przeznaczenia zmieniło się na Europę. Obozy dla uchodźców w sąsiednich krajach były pełne, warunki bytowe niewystarczające, a konflikt nie miał końca, tak jak oczekiwali uciekinierzy. Dlatego uchodźcy decydowali się na emigrację do takich krajów, jak Niemcy, Austria czy Norwegia, w poszukiwaniu lepszego życia. Dopiero po ich pojawieniu się na ulicach miast europejscy przywódcy zdali sobie sprawę z tego, że nie mogą dłużej ignorować problemu. Trudno było wówczas przewidzieć, że promowana przez niemiecką kanclerz Angelę Merkel polityka „otwartych drzwi” już po upływie kilku lat zastąpiona zostanie polityką obrony granic „europejskiej twierdzy”. Szczególnie ostatnie miesiące 2021 roku przyniosły natężenie problemu, w całej UE w równym stopniu angażując uwagę zwolenników obydwu koncepcji, jak i przedstawicieli organizacji humanitarnych, grup ratowniczych, pomocowych oraz stowarzyszeń medycznych.

W nawiązaniu do tych wyzwań, za cel badawczy prezentowanego tekstu przyjęto przybliżenie głównych działań ukierunkowanych na rozwiązywanie kwestii uchodźczej w Europie. Uzupełniono go próbą oceny skuteczności dotychczas stosowanych form wsparcia i pomocy uchodźcom.

\section{Pomoc ekonomiczna w krajach dotkniętych kryzysem}

Unia i jej państwa członkowskie zapewniają ponad połowę światowej pomocy rozwojowej. W 2015 roku, kiedy ONZ przyjęło Agendę na rzecz Zrównoważonego Rozwoju do roku $2030^{3}$, delegacja UE i główne państwa-darczyńcy (czyli przede wszystkim Francja, Niemcy, Szwecja i Wielka Brytania) odegrały kluczową rolę w opracowaniu projektu.

Zaangażowanie UE w globalny rozwój i eliminację ubóstwa jest również ważnym źródłem tzw. miękkiej siły dla państw członkowskich - indywidualnie i zbiorowo. Podobnie jak we wszystkich obszarach polityki zewnętrznej, podejście Unii do migracji zawsze było częściowo napędzane imperatywami politycznymi, które wpływają na ogólną wielkość pomocy, od współpracy politycznej z krajami otrzymującymi pomoc w zakresie handlu, energii i bezpieczeństwa, po odbudowę po wojnach. W ostatnich latach UE podkreśliła inicja-

3 Agenda jest programem przyjętym w 2015 roku. Zapewnia wspólny plan pokoju i dobrobytu dla ludzi i planety. Sygnatariusze uznają, że likwidacja ubóstwa musi iść w parze ze strategiami, które poprawiają zdrowie i pobudzają wzrost gospodarczy, edukację, zmniejszają nierówności. 
tywy polityczne, które wykazują kontrolę nad migracją do Europy, koncentrując się na krajach pochodzenia i tranzytu. Znacznie zwiększyły się też wysiłki na rzecz powstrzymania migrantów poprzez współpracę z rządami w krajach tranzytowych.

Zewnętrzna polityka migracyjna UE przybiera różne formy: od porozumień politycznych, takich jak umowa z Turcją z 2016 roku $^{4}$, po inicjatywy współpracy technicznej, takie jak szkolenia libijskiej straży granicznej. Sztandarowym programem humanitarnym w Turcji jest Sieć Bezpieczeństwa Socjalnego w Sytuacjach Nadzwyczajnych (Emergency Social Safety Net ESSN), program pomocy społecznej, który poprzez pomoc pieniężną pomaga najsłabszym grupom uchodźców zaspokajać ich codzienne potrzeby. Dzięki pomocy w wysokości 1,725 mld euro organizacje humanitarne - te, z którymi UE współpracuje, oraz z turecki Czerwony Półksiężyc i tureckie instytucje rządowe - dystrybuują karty debetowe, które pozwalają rodzinom uchodźców na zakupy niezbędnych towarów. Program ESSN jest największym pojedynczym projektem humanitarnym w historii UE i od października 2019 roku pomaga ok. 1,7 mln osób (Turkey 2019). Projekt ten jest uzupełniany przez wiele innych projektów pomocy humanitarnej dotyczących kwestii ochrony, w tym: doradztwo prawne, wsparcie psychospołeczne, dostęp do dokumentacji cywilnej i specjalistyczne usługi opieki zdrowotnej.

Doświadczona skutkami konfliktu syryjskiego UE od pierwszych dni kryzysu afgańskiego, czyli od sierpnia 2021 roku, stara się zapobiegać ewentualnym masowym migracjom ludności objętej ryzykiem prześladowań. Już w ostatnich dniach sierpnia tego roku ministrowie sprawiedliwości i spraw wewnętrznych zobowiązali się wesprzeć sąsiadów Afganistanu, aby pomóc im w przyjmowaniu osób uciekających przed nowym reżimem talibów i zapobiec nowej fali migrantów zmierzających do Europy. W oświadczeniu końcowym po nadzwyczajnym posiedzeniu Rady w Brukseli ministrowie stwierdzili, że UE jest zdeterminowana, by działać wspólnie z państwami członkowskimi, aby zapobiegać nawrotowi niekontrolowanych, masowych, nielegalnych ruchów migracyjnych, $\mathrm{z}$ jakimi trzeba było się zmagać $\mathrm{w}$ ostatnich latach. Za szczególnie istotne dla sprawy uznano wszechstronne wsparcie dla krajów sąsiadujących z Afganistanem. Plan ten przypomina umowę, którą UE zawarła z Turcją po tym, jak w 2015 roku granice Unii przekroczyło ponad milion migrantów, w tym wielu uciekających przed wojną, biedą, prześladowaniami w Syrii i Iraku (Statement on the Situation in Afghanistan, 2021).

Nieco inne podejście wykazuje UE wobec państw afrykańskich. Wszelkie kontakty z osobami zmuszonymi do przesiedlenia w Afryce zwykle wiążą się z pomocą humanitarną, która zasadniczo polega na zaspokajaniu podstawowych

${ }^{4}$ W 2016 roku UE zawarła umowę z Turcją i postanowiła przyznać jej 6 mld euro na kolejny okres, aby pomóc temu krajowi w kwestii mieszkających tam uchodźców i migrantów. 
potrzeb, a nie na inwestowaniu w trwałe cele długoterminowe, choć ten aspekt w ostatnich latach jest również wzmacniany.

W czerwcu 2017 roku Bank Światowy i Wysoki Komisarz Narodów Zjednoczonych do spraw Uchodźców (United Nations High Commissioner for Refugees - UNHCR) opracowali program dla uchodźców, w ramach którego przeznaczył 2 mld dolarów na wspieranie krajów o niskich dochodach, przyjmujących ponad 25 tys. uchodźców lub mających populację uchodźców na poziomie co najmniej 0,1\% ogółu ludności. Środki te przeznaczono na wsparcie reform politycznych, dotyczących długoterminowych inicjatyw przynoszących korzyści zarówno uchodźcom, jak i społecznościom przyjmującym. Integracja uchodźców w społeczeństwach przyjmujących leży u podstaw tego podejścia, w tym poprzez wspieranie swobody przemieszczania się, pomoc w pozyskiwaniu dokumentów tożsamości i w spełnianiu warunków formalnego uczestnictwa w rynku pracy. To inicjatywa znacząca dla obydwu stron.

Pomoc ekonomiczna w krajach dotkniętych kryzysem, jako walka z napływem uchodźców, opiera się na założeniu, że cała migracja do Europy jest napędzana czynnikami ekonomicznymi, oczekiwaniami socjalnymi. Uprawnia to do sformułowania tezy, iż zwiększenie szans gospodarczych w krajach pochodzenia ograniczy migrację. To rozumowanie nie uwzględnia jednak faktu, że wielu afrykańskich migrantów ucieka przed konfliktami, prześladowaniami i represjami politycznymi, grożącymi im często ze strony własnego państwa. W krajach takich, jak na przykład Erytrea, Mali, Nigeria, Somalia i Sudan Południowy, migracja napędzana jest przede wszystkim strachem przed utratą zdrowia i życia. Ucieczka z własnego kraju, ze zrozumiałego, bliskiego kręgu kulturowego, w takim przypadku to przede wszystkim poszukiwanie bezpieczeństwa i ochrony międzynarodowej. To wielka desperacja i trauma dotkniętych nią ludzi. Dlatego za mało prawdopodobne można uznać, że interwencje rozwojowe w takich przypadkach obejmować powinny przede wszystkim tworzenie miejsc pracy, czy poprawę lokalnych udogodnień (Fine, Dennison, Gowan, 2019). O wiele ważniejsze jest zaspokojenie podstawowych potrzeb biologicznych, opieka medyczna i psychologiczna, pomoc w adaptacji do nowych warunków życia, edukacja i poczucie bezpieczeństwa.

UE i jej państwa członkowskie przekształciły swoje polityki zewnętrzne, w tym współpracę na rzecz rozwoju, tak, aby można było położyć większy nacisk na kwestie związane z migracją. Powszechnie stosowana dotychczas polityczna retoryka ,zajmowania się pierwotnymi przyczynami migracji” została zakwestionowana przez naukowców jako stwarzająca nierealne oczekiwania. Rzeczywiście, dodatnia korelacja między migracją a wąsko rozumianym rozwojem gospodarczym utrzymuje się dotąd, dopóki kraje nie osiągną poziomu średniego dochodu. Kilka kluczowych czynników migracji wiąże się jednak z innymi tzw. zmiennymi pośredniczącymi. Niektóre z nich to: presja demograficzna, bezrobocie młodzieży, realne możliwości zatrudnienia w kraju docelowym, rozwój sieci migrantów i chęć łączenia rodzin (Latek, 2019). 
Nie można także zapominać o istnieniu złożonej interakcji zachodzącej między bezpośrednią pomocą materialną a migracją - interakcji dalekiej od prostej przyczynowości i jednokierunkowej zależności. Zasadniczo zmniejszenie ubóstwa (główny cel pomocy rozwojowej) raczej zwiększa, a nie powstrzymuje, nie redukuje aspiracji migracyjnych. Bardziej globalne podejście do współpracy z krajami trzecimi - takie np. jak ugruntowana już pomoc UE koncentrująca się na dobrym sprawowaniu rządów, infrastrukturze,rozwoju handlu, inwestycji, obszarów wiejskich - wydaje się bardziej obiecujące pod względem skutecznego powstrzymywania migracji. Jednocześnie badania potwierdzają, że migracje międzynarodowe są ważną ścieżką postępu i rozwoju: przekazy pieniężne stanowią narzędzie zmniejszania ubóstwa, a umiejętności i sieci diaspory zapewniają zasoby dla postępu gospodarczego i społecznego (Latek, 2019).

\section{Wsparcie polityczne dla państw pogrążonych w kryzysie}

Sposób, w jaki przedstawia się ruch migracyjny, ma znaczący wpływ na udzielane wsparcie polityczne, a tym samym na podejmowanie decyzji. Migracja jest z natury wysoce polityczna i może powodować podział w obrębie państw członkowskich UE. Podczas gdy prawo i wartości międzynarodowe w nieunikniony sposób rzutują na decyzje rządów dotyczące sposobu reagowania na uchodźców, podobne oddziaływanie mają także władza i interesy narodowe oraz interesy różnych lobbujących na arenie międzynarodowej grup wpływu. Zaangażowanie państw przyjmujących i darczyńców w zakresie pomocy, ochrony i dostarczania rozwiązań dla uchodźców zależy od tego, czy, a jeśli tak, to w jakim stopniu postrzegają uchodźców jako obciążenie lub korzyść w odniesieniu do bezpieczeństwa i wyników rozwojowych. Dowody na to można znaleźć w prawie każdym segmencie systemu reagowania na uchodźstwo i uchodźców: od przeznaczenia datków na pomoc humanitarną przez darczyńców, przez decyzje dotyczące przesiedleń, po decyzje państw przyjmujących w kwestii zapewnienia (bądź nie) uchodźcom swobód społeczno-gospodarczych.

O ile mandat Wysokiego Komisarza Narodów Zjednoczonych do spraw Uchodźców wskazuje, że ma to być organizacja ściśle niepolityczna, o tyle państwa narodowe i organizacje polityczne, w tym UE, chętnie obierają określone stanowiska względem stron konfliktów. Wzmożona migracja ludności, która ma miejsce w ostatnich latach w Europie, jest pokłosiem m.in. konfliktu syryjskiego. Od początku kryzysu UE zmobilizowała wszystkie dostępne narzędzia polityczne i humanitarne w celu wsparcia narodu syryjskiego, pozostając jednym z głównych zwolenników starań ONZ na rzecz rozwiązania politycznego 
i głównym darczyńcą pomocy humanitarnej dla Syryjczyków. Wspólnota opowiada się za niepodległym narodem syryjskim i pracuje na rzecz prawdziwej transformacji politycznej $\mathrm{w}$ tym regionie. Po syryjskim powstaniu obywatelskim wiosną 2011 roku i wynikającej z niego eskalacji przemocy oraz łamania praw człowieka zawiesiła dwustronną współpracę z rządem Syrii i zamroziła projekt układu o stowarzyszeniu (Jongberg, Trapouzanlis, 2021). Od tego czasu UE wstrzymała udział władz syryjskich w swoich programach regionalnych. Także Europejski Bank Inwestycyjny (EBI) zastopował wszystkie operacje pożyczkowe i pomoc techniczną na rzecz tego kraju. Unia ustanowiła, a następnie rozszerzyła ukierunkowane sankcje, w tym embargo na broń, zamrożenie aktywów i zakaz podróżowania członków syryjskiego rządu oraz embargo na ropę naftową. W konsekwencji Syria zahamowała współpracę z Unią na rzecz Regionu Morza Śródziemnego 5 i uczestnictwo w niej. Delegatura UE w Syrii pozostawała otwarta do grudnia 2012 roku, kiedy to UE zaakceptowała Syryjską Koalicję Narodową na rzecz Opozycji i Sił Rewolucyjnych ${ }^{6}$ jako prawowitych przedstawicieli narodu syryjskiego.

UE potępiła również ofensywę tureckich sił zbrojnych w północno-wschodniej Syrii z października 2019 roku, zorganizowaną pod kryptonimem „Źródło pokoju". Była to transgraniczna operacja wojskowa prowadzona przez tureckie wojsko i Wolną Armię Syrii przeciwko Autonomicznej Administracji Północnej i Wschodniej Syrii (Rożawa) oraz Syryjskim Siłom Demokratycznym. Rządy UE zanegowały działania Ankary w związku z jej wtargnięciem na terytorium syryjskie, ale były podzielone co do sposobu reagowania na ten atak. Nie bez znaczenia dla takiego dualizmu pozostawał fakt braku bezpośredniego wpływu unijnych ustawodawców na decyzje bloku zagranicznego w zakresie polityki zagranicznej.

Jednoznacznie natomiast Unia określiła swoje stanowisko wobec kryzysu w Afryce Północnej. Libia, która doświadczyła wojny domowej (wywołanej na fali arabskiej wiosny, a konflikt ten z różnym nasileniem trwa do chwili obecnej), jest jednym z tych krajów, który budzi szczególne zainteresowanie na Starym Kontynencie. UE i jej państwa członkowskie jednoczą się w apelu, aby wszystkie partie libijskie zobowiązały się do trwałego zawieszenia broni i powrotu do procesu politycznego, wspieranego przez ONZ. Stoją na stanowisku, że nie ma wojskowego rozwiązania kryzysu w Libii i niezbędne jest wznowienie procesu mediacji pod przewodnictwem ONZ.

${ }^{5}$ Unia na rzecz Regionu Morza Śródziemnego to międzyrządowa organizacja 43 państw członkowskich z Europy i basenu Morza Śródziemnego: 28 państw członkowskich UE i 15 partnerskich krajów śródziemnomorskich z północy Afryki, Azji Zachodniej i Europy Południowej.

${ }^{6}$ Syryjska Koalicja Narodowa na rzecz Opozycji i Sił Rewolucyjnych to związek ugrupowań opozycyjnych w wojnie domowej w Syrii, która została założona w Dosze, stolicy kataru, w listopadzie 2012 roku. 
Kolejne wyzwania przyniosły wydarzenia w Afganistanie spowodowane wycofaniem wojsk amerykańskich i przejęciem wszelkich aktywów państwowych (w tym najnowszego uzbrojenia i technologii militarnych) przez talibów oraz polityka szantażu uchodźczego zastosowana wobec UE przez doświadczanego sankcjami samozwańczego białoruskiego dyktatora. Państwa UE obawiają się, że przejęcie władzy przez talibów może wywołać powtórkę z kryzysu z lat 2015/2016, kiedy przybycie ponad miliona migrantów, głównie z Bliskiego Wschodu, nadwerężyło systemy bezpieczeństwa i opieki społecznej oraz zwiększyło poparcie dla ugrupowań skrajnie prawicowych (Shields, Stonestreet, 2021).

Wojna hybrydowa na wschodniej granicy Unii i wydarzenia w Afganistanie mogą być źródłem inspiracji dla opracowania wspólnej polityki migracyjnej oraz przyjęcia wspólnego stanowiska wobec talibów. Mogą też Europejczyków jeszcze bardziej spolaryzować. Mogą przynieść spektakularny sukces wspólnotowy, bądź też ujawnić słabości integracyjne i organizacyjne. Mogą także ujawnić siłę bądź bezbronność Wspólnoty jako symbolu współczesnej cywilizacji i postępu. Mogą pomóc w rozwiązaniu zidentyfikowanych już w Europie problemów demograficznych, depopulacyjnych, bądź też poprzez zaniechanie działań - mogą przyzwolić na humanitarną katastrofę. Czas pokaże, czy doświadczenie zdobyte w połowie drugiej dekady XXI wieku przybliży państwa członkowskie UE do osiągnięcia celów zapisanych w traktatach założycielskich i konwencji genewskiej.

\section{Pomoc zbrojna w państwach dotkniętych wojną}

We współczesnym świecie wciąż jest wiele regionów, które borykają się z falą przemocy i destabilizacji. Armed Conflict Location and Event Data w 2019 roku ocenił stan przemocy politycznej i protestów w krytycznych punktach zapalnych w Afryce, Azji i na Bliskim Wschodzie, co pozwoliło stworzyć listę 10 krajów, w których obecnie panują największe konflikty. Należą do nich m.in.:

- rejon Sahelu, gdzie „W wyniku przemocy i klęsk humanitarnych w regionie, w którym niemal 16 mln osób zmaga się z brakiem bezpieczeństwa żywnościowego, ponad milion osób w samym 2018 roku opuściło miejsce zamieszkania" (Kania, 2019);

- Jemen, gdzie od 2015 roku trwa konflikt pomiędzy Ruchem Huti ${ }^{7}$ a Jemeńskimi Siłami Rządowymi, wraz z ich zwolennikami i sojusznikami; konflikt ten wywołał jeden z najgorszych kryzysów humanitarnych w 2019 roku;

${ }^{7}$ Ruch Huti to jemeński ruch o charakterze polityczno-militarnym, skupiający plemiona zajdyckie (jeden z odłamów szyizmu) zamieszkujące głównie północno-zachodni Jemen. 
- Irak, który jest najbardziej narażony na ponowny wybuch wojny domowej;

- Mjanma, gdzie prognozuje się eskalację konfliktu zbrojnego na tle etnicznym;

- Syria, gdzie przewiduje się kolejne przejście do masowych represji;

- Libia, która zagrożona jest fragmentaryzacją i sojuszami zbrojnych grup niepaństwowych (Mid-Year Update: Ten Conflicts to Worry About in 2019).

Instytucją międzynarodową, która wiedzie prym w promowaniu postaw zmierzających ku niwelowaniu konfliktów i eskalacji przemocy, jest m.in. ONZ. Od czasu powstania Organizacja była często wzywana do zapobiegania eskalacji sporów lub do przywracania pokoju po wybuchu konfliktu zbrojnego oraz do wspierania trwałego pokoju w społeczeństwach powstających po wojnach. Przez dziesięciolecia pomagała zakończyć liczne konflikty. Po otrzymaniu skargi na zagrożenie pokoju Rada Bezpieczeństwa najpierw zaleca stronom, by dążyły do porozumienia pokojowymi środkami. Może również mianować specjalnych przedstawicieli lub poprosić o to sekretarza generalnego i skorzystać z jego biur. Może także określać zasady pokojowego rozstrzygnięcia konfliktu. Gdy spór prowadzi do walki, pierwszą troską Rady jest jak najszybsze jego zakończenie. Wiele razy Rada wydawała dyrektywy o zawieszeniu broni, które pomogły zapobiec poważnym działaniom wojennym. Rada rozmieszcza także operacje pokojowe ONZ w celu zmniejszenia napięć na obszarach znajdujących się w trudnej sytuacji.

Zgromadzenie Ogólne ONZ może natomiast wydawać zalecenia dotyczące ogólnych zasad współpracy w celu utrzymania międzynarodowego pokoju i bezpieczeństwa, w tym rozbrojenia. W ramach Organizacji budowanie pokoju odnosi się do wysiłków mających na celu pomoc krajom i regionom w przechodzeniu od wojny do pokoju oraz zmniejszeniu ryzyka wystąpienia destabilizacji w wyniku konfliktu, w tym poprzez wzmacnianie krajowych zdolności w zakresie zarządzania konfliktem oraz budowanie podstaw trwałego pokoju i rozwoju.

Operacje pokojowe ONZ są istotnym instrumentem stosowanym przez społeczność międzynarodową w celu poprawy pokoju i bezpieczeństwa. Pierwsza misja pokojowa ONZ została ustanowiona w 1948 roku, kiedy Rada Bezpieczeństwa zezwoliła na rozmieszczenie ONZ ds. Nadzorowania Rozejmu (UNTSO) na Bliskim Wschodzie w celu monitorowania porozumienia o zawieszeniu broni między Izraelem a jego arabskimi sąsiadami. Od tego czasu na całym świecie przeprowadzono ponad 70 operacji pokojowych ONZ. Misje pokojowe, pierwotnie opracowane jako sposób rozwiązania konfliktu międzypaństwowego, z czasem coraz częściej stosowane były do zażegnywania konfliktów wewnątrzpaństwowych i wojen domowych. Chociaż wojsko pozostaje kręgosłupem większości operacji pokojowych, obecni operatorzy pokojowi wykonują różnorodne, złożone zadania: od pomocy w budowaniu trwałych instytucji rządowych, po monitorowanie praw człowieka i reformę sektora bezpieczeństwa. 
Również NATO jest aktywnym i wiodącym uczestnikiem pokoju i bezpieczeństwa na arenie międzynarodowej. Promuje wartości demokratyczne i dąży do pokojowego rozwiązywania sporów. Jeśli jednak wysiłki dyplomatyczne się nie powiodą, ma ono zdolność wojskową do podejmowania operacji zarządzania kryzysowego samodzielnie lub we współpracy z innymi krajami i organizacjami międzynarodowymi. Około 20 tys. personelu wojskowego bierze udział w operacjach i misjach NATO na całym świecie, zarządzając operacjami naziemnymi, lotniczymi i morskimi. W 2018 roku NATO zainicjowało misję szkoleniową w Iraku, której celem jest zwiększenie zdolności sił bezpieczeństwa Iraku, jego instytucji obrony i bezpieczeństwa oraz krajowych akademii obrony. NATO wspiera również Unię Afrykańską i prowadzi misje policyjne na wniosek swoich sojuszników. Ponadto pomaga reagować na kryzysy związane z uchodźcami i migrantami w Europie i na świecie.

\section{Podsumowanie}

Dobrze zarządzana migracja może sprzyjać rozwojowi zarówno krajów zarówno docelowych, jak i pochodzenia oraz być korzystna dla samych migrantów i ich rodzin. Aby wykorzystać możliwości, wraz z jednoczesnym zminimalizowaniem ryzyka migracji, społeczność globalna musi koniecznie współpracować, ponieważ żaden kraj nie jest w stanie samodzielnie rozwiązać problemu migracji i przymusowych wysiedleń. W tym kontekście Unia Europejska od 2015 roku próbuje wypracować wspólnotowe podejście do migracji, w którego ramach będzie można kompleksowo chronić migrantów i uchodźców oraz pomagać krajom partnerskim w usuwaniu pierwotnych przyczyn nielegalnej migracji i przymusowych wysiedleń. Chociaż wiele inicjatyw zostało już wdrożonych, to brak pełnej jednogłośności nie pozwala na całkowite wyeliminowanie problemów związanych z masową migracją.

Społeczność międzynarodowa, a w szczególności kraje zamożne, nie jest w stanie w znaczący sposób dzielić odpowiedzialności za ochronę ludzi, którzy uciekli ze swoich domów w poszukiwaniu bezpieczeństwa. Niejednokrotnie kraje o niższym i średnim dochodzie robią znacznie więcej niż państwa zachodnie, biorąc na siebie główny ciężar pomocy uchodźcom i migrantom.

U podstaw współczesnego systemu migracji leży strukturalne niedopasowanie pomiędzy ogromnym popytem na wjazd do najbardziej rozwiniętych regionów a stosunkowo niewielką podażą możliwości legalnego wjazdu na teren takich państw. W konsekwencji można je opisać jako system społeczny, uporządkowany splot współzależności, w którym istnieje napięcie między celami kulturowymi i społecznymi wyznaczonymi przez coraz bardziej wspólną kultu- 
rę globalną a środkami dostępnymi do realizacji tych celów (Echeverría, 2020). Działania zarówno polityczne, ekonomiczne, społeczne, jak i kulturowe zawsze mają swoje regionalne, narodowe, wyznaniowe czy też inne ograniczenia oraz czynniki ryzyka konfliktu.

Polityka ma niebagatelny wpływ na przepływ migracji. Poza oficjalnymi programami i działaniami politycznymi poszczególnych krajów funkcjonuje również retoryka polityczna i napięcia w krajach przyjmujących, rozbieżne z rządową linią programową, które mogą zmienić decyzje migrantów o imigracji. Jeśli retoryka jest przeciwko migracji, mogą pojawić się ogólne obawy dotyczące bezpieczeństwa i akceptacji. Niejednorodność podejścia do zagadnienia działań pomocowych zmniejszających rozmiar kryzysu migracyjnego wynika również z niejednorodności źródeł kryzysu. Wielu migruje w następstwie klęsk żywiołowych lub gdy niezbędne do życia zasoby naturalne ulegają wyczerpaniu, stają się niedostępne. Inni migrują z powodu przemocy i niepokojów politycznych, które są bezpośrednim skutkiem ludzkiego zachowania. Wzorce migracji w sytuacjach takich, jak wojna czy ludobójstwo, wyglądają inaczej niż w przypadku kataklizmów: trzęsień ziemi czy suszy. Bezpieczeństwo regionu może wpływać na rozmiar i zakres wzorców migracji. Ponadto niestabilność polityczna może się rozprzestrzeniać, jak w przypadku wojny, podczas której uchodźcy mogą nie być bezpieczniejsi w sąsiednich krajach. Polityka będzie miała na to wpływ, szczególnie w sytuacjach, gdy inne kraje nie będą chronić migrantów.

Wyzwania polityki migracyjnej stawiane obecnie przed kreatorami współczesnej rzeczywistości są coraz trudniejsze i niemal definicyjnie konfliktogenne. Od kryzysu migracyjnego w Libii w 2015 roku, który w wyniku porozumienia z Turcją, z Libią czasowo został zażegnany - wiele zapisów prawnych, umów, postanowień i strategii straciło na aktualności. Zrezygnowano z unijnego projektu przymusowej relokacji, a polityka azylowa wymaga zmian. Jako budzące zastrzeżenia natury prawnej i humanitarnej skrytykowano też rozwiązania ograniczania napływu nielegalnych migrantów drogą zamykania granic przez państwa członkowskie. Wyraźnej zmianie uległo też nastawienie społeczne mieszkańców Europy do migrantów. Niechęć do przyjmowania uciekinierów, w dużej mierze będąca skutkiem powszechnego utożsamiania uchodźstwa z migracją zarobkową i polityką ,grania ludźmi” przez białoruskiego dyktatora - rodzi potrzebę ponownego zdefiniowania polityki migracyjnej, nakreślenia jej celów i metod działania, opracowania, akceptowanych w przestrzeni międzynarodowej, strategii pomocowych zgodnych z zasadami humanitaryzmu, ale i pomocnych w rozwiązywaniu obecnych i prognozowanych europejskich problemów demograficznych, edukacyjnych i zawodowych. Racjonalne, wspólnotowe rozwiązywanie problemów nielegalnej migracji może bowiem przynieść rozwikłanie wielu trudnych europejskich kwestii. Może też przyczynić się do wzmocnienia wspólnotowej spójności i wzajemnego zaufania, niezwykle cennego w podejmowaniu globalnych wyzwań. 


\section{Bibliografia}

Echeverría, G. (2021). Understanding Irregular Migration Through a Social Systems Perspective. Springer International Publishing: New York.

Fine S., Dennison S., Gowan R. (2019). False Moves: Migration and Development Aid. The European Council on Foreign Relation, Policy Brief [October].

Jongberg, K., Trapouzanlis, C. (2021). Fact Sheets on the European Union. European Parlament Report.

Kania, M. (2019). Trudny region: Sahel w cieniu terroryzmu i konfliktów etnicznych. Analiza. Zakład Bezpieczeństwa Narodowego UJ, nr 7(46).

Kluth, A. (2021). UE jak Imperium Rzymskie. Masowe migracje moga doprowadzić Europe do upadku. Pobrano z: https://forsal.pl/swiat/unia-europejska/ artykuly/8233849,masowe-migracje-moga-doprowadzic-europe-do-upadku.html (data dostępu: 21.09.2021).

Latek, M. (2019). Interlinks between Migration and Development. European Parliamentary Briefing, PE 630.351, Brussel.

Mid-Year Update: Ten Conflicts to Worry About in 2019. Pobrano z: https://www. acleddata.com/2019/08/07/mid-year-update-ten-conflicts-to-worry-aboutin-2019/, (data dostępu: 31.10.2019).

Minister Jacek Czaputowicz on Polish Diplomacy Priorities in 2019. Pobrano z: https:/www.gov.pl/web/diplomacy/minister-jacek-czaputowicz-on-polish-diplomacy-priorities-in-2019 (data dostępu: 31.10.2019).

Shields, M., Stonestreet, J. (2021). Afghanistan Could Be Catalyst for Common EU Migration Policy-commissioner. Pobrano z: https://www.reuters.com/world/ china/afghanistan-could-be-catalyst-common-eu-migration-policy-commissioner-2021-09-04/ (data dostępu: 18.09.2021).

Statement on the Situation in Afghanistan. Council of the EU and the European Council. Pobrano z: https://www.consilium.europa.eu/en/press/pressreleases/2021/08/31/statement-on-the-situation-in-afghanistan/ Statement on the situation in Afghanistan (data dostępu: 16.09.2021).

Turkey (2019). Pobrano z: https://ec.europa.eu/echo/where/europe/turkey_en (data dostępu: 31.10.2019). 